\title{
DETERMINING THE LEADING ECONOMIC SECTOR IN BANGLI REGENCY
}

\author{
Dr. I Nengah Suarmanayas \\ Assistant Professor, Department of Business Administration, \\ Ganesha University of Education, Singaraja, Bali-Indonesia
}

\begin{abstract}
This article aims to analyze and find out the economic structure of the Bangli Regency in terms of its contribution to the Gross Regional Domestic Product. Leading economic sectors and commodities as well as the economic linkages of Bangli Regency with the surrounding regions were also examined in this study. Secondary data in the form of the district and provincial Gross Regional Domestic Product (GRDP) data, agricultural commodity production data, and population data, are used as the application of the documentation method in this study. Analysis of the data used is a shift-share analysis tool, location quotient analysis, and gravity models. The results found that the economic growth rate of the Bangli Regency was slower than the general economic growth in Bali Province. Potential economic sectors that can be used as leading sectors in Bangli Regency are the agriculture sector and the service sector. Bangli Regency has strong economic links with Badung Regency. This paper is very important for the Bangli Regency government as a policymaker. The hope, this paper can be a stimulus to drive economic activity in Bangli Regency.
\end{abstract}

Key words: Potential Economic Sector.

Cite this Article: I Nengah Suarmanayas, Determining the Leading Economic Sector in Bangli Regency, International Journal of Management, 11(12), 2020, pp. 2602-2612. http://iaeme.com/Home/issue/IJM?Volume=11\&Issue=12

\section{INTRODUCTION}

Bali Province with its eight districts and one big city has varied GRDP. Several of the areas have a relatively high GRDP, meanwhile, some areas still have a relatively low GRDP. Denpasar City, Badung, Buleleng, Gianyar, and Tabanan regency have high GRDP. On the other hand, Karangasem, Jembrana, and Klungkung districts have a low rate of GRDP compare to the Bangli district, in which GRDP is in the lowest position in five years. GRDP of Bangli district has a significantly increased amount of GRDP. The GRDP value of Rp 3,686.10 billion in 2015 increased to Rp 4,588.86 billion in 2019. Although the increase continues to occur, the GRDP owned by Bangli Regency remains the lowest compared to other districts/cities in Bali Province. To solve this problem, a study needs to be done so that the position of the Bangli Regency is not always at the lowest rank. In contrast to Badung Regency which has the highest 
GRDP and has the largest share of the GRDP of the Province of Bali, in percentage the PDRB share of the Bangli Regency against the GRDP of the Province of Bali is the smallest ie less than 4 percent. Regency / City GRDP in Bali Province Based on 2010 Constant Prices, the Period of 2015-2019 can be seen in table 1.

Table 1 Regency / City PDRB in Bali Province Based on 2010 Constant Prices Period 2015-2019 (Milyar Rupiah)

\begin{tabular}{lrrrrr}
\hline Regency/City & \multicolumn{1}{c}{$\mathbf{2 0 1 5}$} & \multicolumn{1}{c}{$\mathbf{2 0 1 6}$} & \multicolumn{1}{c}{$\mathbf{2 0 1 7}$} & \multicolumn{1}{c}{$\mathbf{2 0 1 8}$} & \multicolumn{1}{c}{$\mathbf{2 0 1 9}$} \\
\hline Jembrana Reg. & $7.576,31$ & $8.027,93$ & $8.452,03$ & $8.924,88$ & $9.421,37$ \\
Tabanan Reg. & $12.644,52$ & $13.420,55$ & $14.141,72$ & $14.951,70$ & $15.789,28$ \\
Badung Reg. & $29.170,24$ & $31.157,37$ & $33.052,05$ & $35.278,50$ & $37.335,77$ \\
Gianyar Reg. & $15.168,55$ & $16.125,28$ & $17.005,12$ & $18.030,40$ & $19.046,60$ \\
Klungkung Reg. & $4.813,39$ & $5.115,61$ & $5.387,61$ & $5.683,75$ & $5.992,74$ \\
Bangli Reg. & $3.686,10$ & $3.916,10$ & $4.124,22$ & $4.350,92$ & $4.588,86$ \\
Karangasem Reg. & $8.991,75$ & $9.524,23$ & $10.006,13$ & $10.554,40$ & $11.134,80$ \\
Buleleng Reg. & $18.818,62$ & $19.950,72$ & $21.023,60$ & $22.204,10$ & $23.437,49$ \\
Denpasar City & $28.422,70$ & $30.273,39$ & $32.105,35$ & $34.168,70$ & $36.164,89$ \\
Bali Province & $129.126,60$ & $137.296,50$ & $144.933,30$ & $154.110,00$ & $162.783,90$ \\
\hline
\end{tabular}

Sumber : BPS Provinsi Bali., 2020

Based on the table above, it can be seen that Bangli Regency has the lowest GRDP. Based on the sector, Bangli Regency is built by three dominant sectors, namely, 1) agriculture sector, forestry, and fisheries by 27.23 percent, 2) the Provision of Accommodation and Food and Beverage sector by 13.12 percent, and 3) is the Government Administration, Defense and Compulsory Social Security sector of 10.67 percent. In this regard, it is very important to conduct a scientific study to find out the economic structure of the Bangli Regency in terms of its contribution to the GRDP.

Potential sectors at the provincial level may not necessarily have potential in a region (Taufiq \& Syirod, 2002; Yusuf, 1999; Todaro, 2000). Leading sectors must have advantages, namely comparative superiority and competitive advantage. Comparatively, the superior sector is having the support of economic, social, and institutional resources of an area such as ownership of natural resources, human resources, infrastructure, and others (Widodo, 2006). The competitive sector is the efficient management of the use of these resources in production, consumption, and distribution and the growth rate tends to be fast (Almuzani, 2002; Budiharsono, 2001; Iriani, 2006). Comparative advantage is more specific or ownership of the factor of production (given) while competitive advantage focuses on effortable management.

Development is a process or way carried out by a country to continue to reach and improve the prosperity and welfare of the community (Bungin, 2009; Boediono, 1981; Glasson, 1990; Kohar et al., 2004). Development can be seen from the economic growth and progress of the social conditions of the community. Economic growth is a process of increasing the production of goods and services in economic activities of the community, while the social conditions of society are a process of improving the quality of life of the community as a whole (Todaro, 2000). For this reason, development must lead to a total change in society as an effort to adjust the social system as a whole, without ignoring the diversity of basic needs and desires of each individual, social and cultural group and region or region (Isserman, 1997; Kuncoro, 2002; Rudi, 1999). Policy changes in the structure of the economy must be developed in harmony with challenging global developments in terms of product excellence and competitive ability (Sidin, 2001). 
The key to the success of the decentralized system through autonomy is the regional development policy which emphasizes the specific characteristics of the region concerned (endogenous development) (Siller et al., 1991; Setyawati et al., 2003). This is done by using the potential of human resources, institutions, and physical resources locally (Sidin, 2001). This orientation leads to the growth of regional initiative and creativity in the development process. These actions can create new job opportunities and stimulate productive activities. Finding the superior potential of an area is very important given the diversity of economic activities, both in the primary, secondary and tertiary sectors. Indicators commonly used to measure the success of regional economic development can be seen from the structure and development of gross regional domestic product (GRDP). Next this study aims to determine the potential economic sector and to know the economic linkages of Bangli regency with surrounding areas.

\section{METHODOLOGY}

This research was conducted in Bangli Regency with a consideration that Bangli Regency has the lowest GRDP between the nine regencies/cities in Bali. Besides, the share of GRDP from Bangli Regency to the GRDP of Bali Province is also hit the lowest button. The growth rate is also low so planning is needed to increase the GRDP of Bangli Regency. The data used to support the analysis in this study are secondary data in the form of quantitative data, namely GRDP data according to the field of business at the constant price of 2010 in Bangli Regency for the period of 2015 - 2019, and GRDP according to the field of business at the base of the 20102010 Bali Province period constant prices - 2019. The variables used in this study are 1) Gross Regional Domestic Product (GRDP) of Bali Province and 2) Gross Regional Domestic Product (GRDP) of Bangli Regency.

The data collection method used in this research was the documentation method. Data was obtained by digging up data from reports, notes, or books related to this study (Sudarmono, 2006; Sugestina, 2002; Syafaat \& Supena, 2000) such as the 'Bangli Dalam Angka' book, the 'PDRB Provinsi Bali', the 'PDRB Kabupaten Bangli', and others. The analytical model used in this study was the Shift Share analysis to determine the economic structure of the Bangli district, the Location Quotient (LQ) analysis was used to determine the leading sectors and leading commodities, and the gravity model analysis to determine regional interactions.

\section{RESULTS AND DISCUSSION}

\subsection{Analysis of Shift Share}

Shift share analysis was used to determine the economic structure of the Bangli Regency during the 2015-2019 period. The results of the analysis were used to explain the different economic growth rates between the regencies and provinces. To get the factors that cause sectoral changes in Bangli Regency with Bali Province as a shaded area, various calculation stages were carried out, namely national growth $(\mathrm{N})$, industrial mix $(\mathrm{M})$, or proportional shift and competitive advantage $(\mathrm{C})$ or differential shift. In this article, the shift-share analysis used was the classic shift-share analysis and Estaban Marquiles (E-M) modified shift-share analysis. The purpose of the Estaban Marquiles modified shift-share analysis was to cover the shortcomings of the classic shift-share analysis. The following table 2 presents the results of the classic shift-share analysis of Bangli Regency in 2015-2019 in million rupiah.

In the classic shift-share analysis of the Bangli Regency in the 2015-2019 period, the value of GRDP Bangli Regency changes was 186,571 million rupiahs. The growth was influenced by the growth component of the Bangli Regency amounting to 227,418 million rupiahs, an industry mix of $(-29,531)$ million rupiahs, and competitive advantage of $(-11,315)$ million rupiahs. The result of the shift-share analysis of Esteban-Marquillas modification in Table 3 shows that the competitive advantage component of the modified Esteban-Marquillas produced competitive 
advantage value with C'ij homothetic employment of (- 38,252 million rupiah) and Aij allocation effect which was valued at 26,937 million rupiahs.

Table 2 Results of Classic Shift Share Analysis of Bangli Regency Period 2015-2019(million rupiah)

\begin{tabular}{|c|c|c|c|c|}
\hline \multirow[b]{2}{*}{ Business Field } & \multicolumn{3}{|c|}{ Component } & \multirow[b]{2}{*}{ Changes (Dij) } \\
\hline & $\begin{array}{c}\text { Regional } \\
\text { share (Nij) }\end{array}$ & $\begin{array}{c}\text { Proportional } \\
\text { shift (Mij) }\end{array}$ & $\begin{array}{c}\text { Different } \\
\text { Shift (Cij) }\end{array}$ & \\
\hline 1. Agriculture & 81.940 & -46.536 & 21.939 & 57.343 \\
\hline Mining and Quarrying & 376 & -13 & -260 & 103 \\
\hline $\begin{array}{l}\text { 3. Processing industry } \\
\text { 4. Electricity, Gas and Clean }\end{array}$ & 17.441 & 4.748 & -2.707 & 19.481 \\
\hline Water & 995 & 345 & 548 & 1.887 \\
\hline 5. Building & 11.550 & -1.151 & -4.594 & 5.804 \\
\hline $\begin{array}{l}\text { Hotel \& Restaurant Trade } \\
\text { Transportation and }\end{array}$ & 58.644 & 16.300 & -31.137 & 43.807 \\
\hline $\begin{array}{l}\text { Communication } \\
\text { Finance, Rental and Perush }\end{array}$ & 4.714 & 1.701 & -3.167 & 3.248 \\
\hline Services & 7.912 & -1.888 & 1.260 & 7.284 \\
\hline 9. Services & 43.847 & -3.036 & 6.804 & 47.614 \\
\hline Total & 227.418 & -29.531 & -11.315 & 186.571 \\
\hline Percentage of Growth & 121,89 & $-15,83$ & $-6,06$ & 100 \\
\hline
\end{tabular}

Table 3 Esteban-Marquillas Modified Shift Share Analysis Results Bangli Regency Period 2015-2019 (million rupiahs)

\begin{tabular}{lrrr}
\hline \multirow{2}{*}{ Business Field } & \multicolumn{3}{c}{ Components of Competitive Advantage } \\
\cline { 2 - 4 } & \multicolumn{1}{c}{ C'ij $^{\prime}$} & \multicolumn{1}{c}{ Aij } & Cij = C'ij + Aij \\
\hline 1. Agriculture & 13.118 & 8.821 & 21.939 \\
2. Mining and Quarrying & -976 & 716 & -260 \\
3. Processing industry & -3.338 & 631 & -2.707 \\
4. Electricity, Gas and Clean Water & 1.864 & -1.316 & 548 \\
5. Building & -3.496 & -1.099 & -4.594 \\
6. Hotel \& Restaurant Trade & -37.175 & 6.039 & -31.137 \\
7. Transportation and Communication & -16.002 & 12.835 & -3.167 \\
8. Finance, Rental and Perush Services & 2.734 & -1.473 & 1.260 \\
9. Services & 5.019 & 1.785 & 6.804 \\
\hline \multicolumn{1}{c}{ Total } & -38.252 & 26.937 & -11.315 \\
\hline
\end{tabular}

Source: Data processedAnalysis of Location Quotient Sectors and Commodities

Based on the results of the LQ analysis of each sector in the Bangli Regency, there are three sectors in which LQ values are greater than one, hereinafter referred to as the base sector. The base sectors in Bangli Regency are the agriculture sector, the construction sector, and the service sector. Of the three base sectors in Bangli Regency, the agricultural sector is the base sector that has the highest LQ value of 1.77, the construction sector of 1.29 , and the services sector of 1.42. Furthermore, it would be further analyzed to the commodity stage of each base sector. However, the analysis of the building sector was not continued because of limited data.

The agricultural sector was divided into five sub-sectors namely the food crops sub-sector, the estate crops subsector, the livestock subsector, the forestry subsector, and the fisheries 
subsector. Then LQ analysis was performed on each subsector. Commodities in the food crops sub-sector in Bangli Regency were grouped into 3 groups, namely the food crops group, the vegetable group, and the fruit group. After analysis, the commodities in the foodstuffs group were the commodity of paddy and sweet potato and the biggest LQ in the field of paddy (4.12). In the vegetable group, the basic commodities were onion, garlic, cabbage, chili, tomatoes, beans, and the biggest LQ value in the garlic commodity $(5,28)$. In the group of fruits that become basic commodities were avocado, jackfruit, orange, papaya, banana, pineapple, and the largest LQ value on citrus fruit commodities (4.99).

In the plantation subsector, Bangli Regency has eight types of plantation commodities. LQ analysis results showed that Arabica coffee was the only base commodity in the plantation subsector in Bangli Regency. This could be seen from the LQ value of Arabica coffee commodities of 10.46. Seven other commodities had an LQ value smaller than one which indicated non-base commodities. The livestock subsector was grouped into two groups namely livestock and poultry groups. In the herding group there were no base commodities. This could be seen from the LQ value smaller than one. In contrast to the poultry group which had two basic commodities namely laying hens and broilers. Broilers had a greater LQ value than laying hens that is equal to 1.51. The results of the analysis in the fisheries sub-sector showed that of the five types of fish commodities in the Bangli Regency there are three basic commodities namely tilapia, tilapia, and tawes. The biggest LQ value owned by Mujair Fish is 2.36.

The services sector was divided into two sub-sectors namely the general government subsector and the private subsector. Analysis of the general government subsector was not continued because of limited data. The results of the LQ Analysis in the Private Subsector in Bangli Regency showed that of the three types of sub-subsectors, there are two sub-subsectors which were the basic sub-subsectors, namely personal and household services with an LQ value of 1.31 and entertainment and recreation services with an LQ value of 1.13.

\subsection{Gravity Model Analysis}

Gravity model analysis was used to analyze the extent of economic ties between Bangli Regency and surrounding districts. The greater the coefficient of gravity between regions, the stronger the attraction between regions. The results of the gravity model analysis showed that Badung Regency had the highest gravity coefficient of the five districts directly bordering the Bangli Regency. While, the smallest gravity coefficient was owned by Gianyar Regency. This indicated that Bangli Regency had strong economic links with Badung Regency and had weak economic links with Gianyar Regency.

Table 4 Bangli Regency's Gravity Index with the Surrounding Regions in 2019

\begin{tabular}{clcc}
\hline No & Regency & $\begin{array}{c}\text { Distance from Bangli Regency } \\
(\mathrm{Km})\end{array}$ & $\begin{array}{c}\text { Gravity } \\
\text { coefficient value }\end{array}$ \\
\hline 1 & Gianyar & 29 & 150814517,2 \\
2 & Karangasem & 60,6 & 23250624,91 \\
3 & Buleleng & 63,7 & 33124065,94 \\
4 & Klungkung & 35 & 29981180,96 \\
5 & Badung & 43,8 & 60991313,88 \\
\hline
\end{tabular}

Source: Data processed

\section{DISCUSSION}

\subsection{Economic Structure of Bangli Regency}

The economic development of the Bangli Regency is slower than the growth of the Province of Bali. This is indicated by the negative overall industry mix value. By sector, there were four 
sectors whose growth is faster than the average economic growth of the Province of Bali, namely the processing industry, electricity, gas and clean water, trade, hotels, and restaurants as well as the transportation and communication sector. The trade, hotel, and restaurant sector was the sector that has the highest industrial mix value. This means that this sector at the provincial level has faster growth than the average economic growth, considering that Bali Island is one of the popular tourist destination islands in Indonesia. While the sector that had the lowest industrial mix value was the agricultural sector. This means that the agricultural sector at the provincial level has growth that is slower than average economic growth.

Competitive advantage shows how far the competitiveness of a sector in Bangli Regency compared to the same sector in the Province of Bali. Overall sectoral competitiveness in Bangli Regency is lower than in Bali Province. This is indicated by the negative value of the competitive advantage. However, if viewed by sector, four sectors have the higher competitiveness than the same sector in the Province, namely agriculture, electricity, gas and clean water, finance, leasing and business services, and the services sector. However, the one with the highest competitiveness was the agriculture sector and was supported by the foodstuffs sub-sector which has quite high competitiveness. While the sectors that had the lowest competitiveness are the trade, hotel, and restaurant sectors with the value of the competitive advantage.

Based on the analysis of shift-share modification of Esteban-Marquillas, in aggregate Bangli Regency does not have a competitive advantage but has a specialization. However, if seen from the effect of allocation per sector in Bangli Regency, two sectors have competitive advantage and specialization, namely the agricultural sector and the service sector. This competitive advantage is due to the natural conditions in the Bangli Regency which support the development of agriculture. Specialization is also created due to the potential of large natural resources and the role of large market demand for local agricultural outputs.

\subsection{Main Sector of Bangli Regency}

LQ analysis results showed that there were three basic sectors for Bangli Regency, namely the agriculture sector, the construction sector, and the services sector. LQ analysis emphasizes comparative advantage so that these three sectors have a comparative advantage in Bangli Regency. According to Tarigan (2004), several factors can make an area have a comparative advantage, including natural conditions (given), it can also be due to the efforts of humans or their people mastering special skills. Bangli Regency with an area that is high land has cool cold weather and high rainfall, making this area suitable for agricultural activities. In addition to the agricultural sector, Bangli Regency also had a comparative advantage in the building sector. This has happened along with the rapid development of physical facilities and infrastructure in the area, so the building sector is one that has the opportunity to continue to grow. This situation occurred not only in Bangli but also in Bali in general. The service sector is also a sector that has a comparative advantage in Bangli Regency. One reason is the increase in the number of state servants in the government environment which has increased from year to year.

\subsection{Main Commodity of Agriculture Sector in Bangli Regency}

The focus of development in the Bangli Regency still relies on the agricultural sector in a broad sense because almost in part ie 58.85 percent of the population aged 15 years and overwork in the agricultural sector. The composition of the agricultural sector is supported by the food crops sub-sector which provides the largest contribution. The results of food crop production from year to year experience fluctuations that are very dependent on the harvested area for food. Judging from the use of land in Bangli, 69.83 percent is used as agricultural land. However, 
paddy fields in Bangli are only 5.58 percent, so, naturally, the production of lowland rice is quite small and lowland rice is not a leading commodity in Bangli. Paddy fields in Bangli are advanced commodities because most of the rice production in Bali comes from Bangli but the growth rate is still low.

Referring to food crop production in 2019 , the highest contribution was achieved by paddy and sweet potato commodities, but their growth has fluctuated during the last five years so that they are referred to as developed but depressed commodities. The contribution of soybeans and lowland rice is the smallest, but when viewed in terms of growth, including the fast-growing so that both these commodities have the potential to be developed. Food crop commodities are not spread evenly in four districts in the Bangli Regency. Paddy rice has the potential to be developed in three districts namely Susut, Bangli, and Tembuku. While paddy fields have the potential to be developed in Susut and Kintamani. The potential of corn commodity to be developed in Kintamani and cassava has the potential to be developed in Bangli District. Sweet potatoes and potatoes were developed in the Districts of Bangli and Kintamani. Peanuts and soybeans have the potential to be developed in Tembuku and Kintamani.

Horticultural commodities are trade commodities in which their development plays a strategic role in supporting the improvement of regional economic development. Bangli has regional potential for horticultural crops, both vegetables and fruit plants. Some vegetable commodities have a large contribution to the production of Bali, such as garlic plants which have a share of up to 87.46 percent and onion plants with a share of 80.06 percent. Other commodities are beans and cabbage plants whose production is more than 40 percent of Bali's production. Garlic and chili are advanced commodities but are still depressed because the growth rate is still below the provincial growth rate. While onion commodities, cabbage, beans, and tomatoes in addition to advanced commodities are also commodities that are growing rapidly so that it can be said to be a leading commodity in Bangli. Vegetable crops are more focused on Kintamani because geographical and climatic conditions in Kintamani support the growth of vegetable crops. Potential distribution of vegetable plants in Kintamani are commodities of shallots, garlic, cabbage, tomatoes, and beans.

Fruit commodities also determine the direction of economic growth in Bangli. Some types of fruits make a very large contribution to Bangli Regency and viewed from the product also gives a large share to the Province of Bali. Oranges that are already famous in Bali, often called Kintamani Oranges, provide a share of 68.52 percent of Bali production. Kintamani oranges have high competitiveness compared to oranges originating from other regions. Therefore, the quality needs to be maintained and even improved so that it can compete with imported oranges that are often used in hotels and restaurants. Other commodities that are superior sectors are papaya by 50.47 percent and bananas 45.88 percent. Pineapple is also a commodity that has a large contribution of 35.46 percent, but the growth rate of pineapple is still below the growth rate of Bali so it is said to be an advanced commodity but is depressed. Potential areas for fruit development are spread in four sub-districts in Bangli Regency. However, several commodities are very potential to be developed in the Kintamani region, namely oranges, mangoes, and bananas. If this potential can be exploited properly, one of which is by improving the quality of horticultural products, Bangli Regency as the largest agribusiness center in Asia can be realized.

The coffee commodity is one of the mainstay commodities of plantations in Indonesia. In addition to its role as a producer of industrial raw materials, coffee has a big role in increasing export earnings, farmers' income, employment, and regional development. The existence of Arabica Coffee in Bangli Regency has gained national and international recognition. The area of coffee plantations is 4,358 hectares and 4,003 hectares are Arabica coffee types. The potential development of Arabica coffee is located in the Kintamani region. Arabica coffee is a 
comparatively superior commodity in the form of support of natural conditions so that Arabica coffee is widely cultivated by the population.

The livestock subsector has a huge potential, because the local market needs for livestock are very large, especially for tourism needs, which so far are still supplied by imported meat and local needs. For this reason, more livestock germs are needed that can be bred in the hope of reducing the supply of imported meat. Even better if the meat has a high quality so that it can meet the needs of hotels and restaurants in Bangli Regency. Bangli Regency has the potential for development in the field of animal husbandry including fattening and breeding of cows, laying hens, broilers, and fattening and breeding of pigs. However, if seen from the contribution to the livestock population in Bali, only laying hens and broilers have a significant contribution among other types of livestock, although its contribution is only around 20 percent. Laying hens is a leading commodity in Bangli Regency because it has a large contribution and is growing fast. While broilers, although their contribution is greater than laying hens, their development is still lower than the province so that it is said to be an advanced commodity but is depressed. Livestock and poultry development areas are spread in four districts, such as cattle, although 56.80 percent is cultivated in the Kintamani area. The population of Bangli, like most other Balinese people, does a lot of work on pigs, either for self-consumption during religious holidays or for sale or cultivation. So that the pig population in each district is almost evenly distributed around 4,000 pigs per district. Laying hens are focused in the Districts of Susut and Kintamani, only a small portion is cultivated in the Districts of Bangli and Tembuku.

The forestry sub-sector has a very strategic function in the supply of timber from forest products for building materials and raw materials for handicrafts and industry, as well as maintaining the balance of water use in Bali Province in general and Bangli in particular. The area of forest in Bangli Regency is 9,341.28 hectares consisting of protected forests, limited production forests, nature reserve forests, nature tourism forests, and distribution of community forests. Of these the most extensive protected forests are around 6,239.01 Ha. The rapid development of development and tourism has led to the need for wood as a building material and as a raw material for governance for tourists in the future is urgently needed, so in the future, it is necessary to develop albesia wood cultivation as multipurpose wood.

The fisheries subsector also has a strategic role as a source of new growth in efforts to improve the economy of the Bangli Regency in the future, especially aquaculture in Lake Batur waters. Mujair is a well-known commodity that is cultivated in Bangli Regency and is a superior commodity in Bangli Regency. Judging from its high contribution of 40.55 percent, it makes Mujair Fish an advanced and rapidly developing commodity. Besides tilapia, Tawes contributes almost dominantly to the Tawes population in Bali so that Tawes is also a leading commodity in Bangli Regency. The most potential fisheries commodities to be developed in Lake Batur with the floating net cage system (KJA) are tilapia with an area of land that has just been utilized an average of 0.8 ha per year from the potential land area of Lake Batur waters that can be developed is still very broad, namely a maximum of 5 - 10 percent of the Lake Batur waters area is 1,607.50 Ha. Fish production in 2010 amounted to 1,788.22 tons for aquaculture products, while the catch was 213.5 tons.

Leading commodities produced by each region differ according to the conditions and potential of each region. The results of a study conducted by Buhana and Masyuri (2006) in the Brebes Regency showed that the dominant and competitive growing commodities were potatoes, shallots, chilies, cloves, and milkfish. There are similarities with the Regency of Bangli that shallots are a superior commodity but different from the case of potatoes which are a backward commodity in Bangli Regency. Kohar and Suherman (2004) produced eight types of superior fish commodities from 24 fish species in the Cilacap Regency including cakalang, layur, cone, shrimp, squid, snapper, black pomfret, and white pomfret. The commodity is 
different from the fishery commodities produced by the Regency of Bangli consisting of tilapia fish, tilapia, and Tawes. In contrast to the superior commodities in East Kotawaringin Regency (Puji, 2006), coffee and lake fisheries which are the leading commodities in Bangli Regency are the least developed commodities in Kotawaringin Regency, but there are also similarities, namely laying hens which are both superior in the two regions. The main commodity of Bali Province studied by Hendayana (2003) states that some of the superior commodities in the Province are superior in Bangli Regency, namely laying hens, coffee, oranges, papaya, bananas, tomatoes, and cabbage. But the superior pork commodity in Bali Province is not the same as the situation in Bangli Regency which is a lagging commodity as well as a clove.

\subsection{Main Commodities in the Bangli Regency Services Sector}

The Services Sector consists of two subsectors, namely the public government sector and the private subsector. The private subsector consists of 3 sub-sectors namely social services, entertainment and recreation services as well as personal and household services. Community social services include education services, health services, orphanages, and other community services managed by the private sector. This service group is growing rapidly in Bangli Regency, this is due to the increasingly widespread private education services such as tutoring institutions that offer a variety of study guidance packages, doctor's practices and midwife practices that offer ease of facilities. Entertainment and recreation services are all activities of companies or private institutions engaged in entertainment, recreation, and cultural services such as radio broadcasting, television, drama shows, dance, music, and amusement parks. Personal and household services include all types of service activities that generally serve individuals and households, for example motor vehicle repair services, repair services for household equipment, and other personal services such as laundry, barber, salon, tailor, and others. This activity is quite a lot in Bangli Regency but it is not in line with the improvement in quality and innovation offered by service providers because this work is done not based on expertise or livelihood but only as a side job. so this activity is quite advanced but depressed. In Bangli Regency which is a superior activity is entertainment and recreation services. This is due to the large number of domestic and foreign tourists visiting tourist sites that are managed by the private sector such as the Trunyan tourism object, the peak of writing, Penglipuran village, and other tourist attractions.

\subsection{Economic Linkages of Bangli Regency}

Bangli Regency has strong economic links with Badung Regency. This closeness shows the mobility of economic resources such as labor flows and production output between the regions. Badung Regency is the center of economic growth and tourism. With the strong economic linkages between Bangli Regency and Badung Regency, it is expected to be able to be a stimulus to move the economic activities of the Bangli Regency so that it can progress like the economy of Badung Regency.

Badung Regency has the highest attachment to Bangli Regency. This indicates that the city center always has an attraction to the surrounding area. This is in line with Sabana's research (2007) which shows that the highest gravity value is owned by Pekalongan City and Batang Regency. This happens because of the attraction of the City of Pekalongan as a business center that has a variety of educational, health, and shopping facilities. Likewise with the research of Setyowati and Trisnawati (2003) which states that the most powerful interaction is Surakarta City with Sukoharjo Regency where Surakarta City is the center of the city. 


\section{CONCLUSION}

The results showed that the economic growth rate of the Bangli Regency was slower than general economic growth in the Province of Bali. Potential economic sectors that are used as leading sectors are the agricultural sector and the services sector. Bangli Regency has strong economic linkages with Badung Regency and has weak economic links with Gianyar Regency. The findings from this study are expected to receive serious attention from policymakers. To that end, the Bangli Regency government as a policymaker should prioritize sectors that have been identified as superior, however other sectors will still receive proportional attention. Some leading sectors of the region should not only be maintained but should continue to be developed to be able to encourage the growth of the GDP of the Regency of Bangli for future development

\section{REFERENCES}

[1] Almuzani. Identifikasi Sektor Dalam Rangka Meningkatkan Pertumbuhan Ekonomi Kabupaten Aceh Tenggara. Yogyakarta : Universitas Gadjah Mada. 2002.

[2] Budiharsono, S. Teknik Analisis Pembangunan Wilayah Pesisir dan Lautan. Jakarta : PT.Pradnya Paramita. 2001.

[3] Buhana, E., dan Masyuri. Analisis Komoditas Unggulan Sektor Pertanian di Kabupaten Brebes. Agrosains 19(1) : 85, 2006.

[4] Bungin, Burhan. Penelitian Kualitatif: Komunikasi, Ekonomi, Kebijakan Publik dan Ilmu Sosial lainnya. Jakarta : Kencana. 2009.

[5] Boediono. Teori Pertumbuhan Ekonomi. Seri Sinopsis Pengantar Ilmu Ekonomi No.4. Yogyakarta : BPFE. 1981

[6] Glasson, Jhon.. Pengantar Perencanaan Regional (terjemahan oleh Paul Sitohang) Jakarta : LPFE-UI. 1990

[7] Hendayana, R.. Aplikasi Metode Location Quotient (LQ) dalam Penentuan Komoditas Unggulan Nasional. Informatika Pertanian Vol $12: 6-7.2003$

[8] Iriani, A.A. Analisis Struktur Ekonomi dan Sektor Basis di Kabupaten Klungkung (tesis). Denpasar : Universitas Udayana. 2006.

[9] Isserman, Andrew.M. The Location Quotient Approach for Estimating Regional Economic Impact. AIP Journal. 1997.

[10] Kohar, Abdul., dan Suherman, Agus. Analisis Loqation Quotient (LQ) dalam Rangka Penentuan Komoditas Ikan Unggulan Perikanan Tangkap Kabupten Cilacap. Semarang : Universitas Diponegoro. 2004.

[11] Kuncoro. Evaluasi Penetapan Kawasan Andalan : Studi Empiris di Kalimantan Selatan 19931999. Jurnal Ekonomi dan Bisnis Indonesia. Vol 17. No.1.2002.

[12] Miller, M M., Gibson, J L,. dan Wright, G N.. Location Quotient Basic Tool for Economic Development Analysis. Economic Development Review, 9(2):65, 1991.

[13] Puji, F. Arahan Perwilayahan Komoditas Unggulan di Kabupaten Kotawaringin Timur. Semarang : Universitas Diponegoro. 2006. 
[14] Rudi, Baharudin.Pengembangan Wilayah Potensi Provinsi DIY (pendekatan teoritis), Jurnal Ekonomi. Vol.4. No.2 VIII. 1999.

[15] Sabana, Choliq.. Analisis Pengembangan Kota Pekalongan sebagai Salah Satu Kawasan Andalan di Jawa Tengah Semarang : Universitas Diponegoro. 2007.

[16] Setyawati, Erma, dan Trisnawati, Rina.. Analisis Potensi Daerah untuk Mengembangkan Wilayah di Eks-Karisidenan Surakarta menggunakan Teori Pusat Pertumbuhan, Jurnal Akutansi dan Keuangan. Surakarta: FE UMS. September, Vol 2,No 2. 2003

[17] Sidin, Fashbir, N. Strategi Kebijakan Pembangunan dalam Otonomi Daerah, Jurnal Ekonomi dan Manajemen. No 1:15-37.2001.

[18] Sudarmono, Mulyanto. Analisis Transformasi Struktural, Pertumbuhan Ekonomi dan Ketimpangan antar Daerah di Wilayah Pembangunan I Jateng Semarang : Universitas Diponegoro, 2006.

[19] Sugestiana, Iman. Identifikasi Sektor Unggulan dalam rangka Meningkatkan Pertumbuhan Ekonomi Kota Bandung, Yogyakarta : Universitas Gadjah Mada, 2002.

[20] Syafaat dan Supena.Analisis Dampak Krisis Ekonomi terhadap Kesempatan Kerja dan Identifikasi Komoditas Andalan Sektor Pertanian di Wilayah Sulawesi : Pendekatan InputOutput, Jurnal Ekonomi. Vol.5, No.1, 2000.

[21] Tarigan, Robinson.. Ekonomi Regional Teori dan Aplikasi. Edisi Revisi. Jakarta : Bumi Aksara. 2004

[22] Taufiq, M. dan Syirod, S. Potensi Relatif Sektor-Sektor Ekonomi Provinsi Sumatra Selatan. Jurnal Kajian Ekonomi. Vol.1. No.1, 1-13, 2002.

[23] Oseweuba Valentine Okoro, "Oil Abundance \& Economic Growth: A Simple Analysis of Economic Trends", Global Journal of Engineering Science \& Researches, 2014, 1(7), pp- 7685

[24] Todaro, Michael. Perkembangan Ekonomi. Edisi Kelima. Jakarta : Bumi Aksara.2000.

[25] Yusuf, M.. Model Rasio Pertumbuhan (MRP) Sebagai Salah Satu Alat Analisis Alternatif Dalam Perencanaan Wilayah dan Kota - Aplikasi Model: Wilayah Bangka-Belitung, Ekonomi dan Keuangan Indonesia (EKI). Vol XI.VII No 2,1999, Jakarta

[26] Widodo. Perencanaan Pembangunan : Aplikasi Komputer. Yogyakarta : UPP STIM YKPN Yogyakarta. 2006. 